\title{
ON ACCESS TO UNIVERSITY INFORMATION RESOURCES
}

Paradigm of access to information resources has been radically changed due to developments in ICT. While old paradigm said that "University is buildings surrounding the library" under new paradigm databases of digital information sources are the heart of University. Model of building university digital information sources and method of access to them is presented in this contribution with the stress put on legislative aspects.

Key words: university information resources, online access, libraries, copyright.

\section{Introduction}

University educational process is, more and more, organized around digital information sources having usually form of digital library. However, digital library itself is only partial solution of the problem. New trends are heavily discussed in literature - see for example Dobre ${ }^{1)}$, Agnew ${ }^{2)}$, Teich ${ }^{3)}$. While technological solutions are available in a readymade form, organizational and, especially, legal aspects have to be designed case by case. Model of building university digital information sources and method of access to them is presented in this contribution with the stress on organizational and legislative aspects, respectively. The paper is organized in the following way: relevant trends are outlined in the first paragraph; second paragraph is devoted to the analysis of Slovak copyright act from the point of view of digital information resources, model of solution is presented in the third paragraph and key points of the design of system of access to study literature are summarized in conclusions.

\section{Trends in organization of university educational process}

The following trends are clearly visible today:

1. Shift from traditional lecturing to discussion groups While under old educational paradigm a lecture was the key component of university educational process and, at the same time, the main source of information, new paradigm put stress on student's individual work with digital information resources.
2. Shift from making notes through copying and highlighting to making electronic notes

Times when students made handwritten notes are over and copying text from books and subsequent highlighting of important sentences is on the decline. Trend is towards editing/commenting digital texts.

3. Shift from information deficiency to information overload Lack of information resources due to limited number of available copies of book in the library, limited offer from catalogue is replaced by a flood in information of various quality. The more and more is perceived a lack of traditional library services, e.g. classification of resources.

4. Shift from linear structure of information resources to nonlinear (hypertext) structure

A book represents an information space that is limited by size, time invariable, linearly organized and meets the conceptual characteristics of "work" according to Slovak copyright act ${ }^{4}$. Digital information resources are, as a rule, of a nonlinear nature. This feature allows for theoretically unlimited expansion of information spaces. Moreover, such a space consists of "works" of many authors, not excluding foreign ones. Another feature of such digital space is its granularity, i.e. possibility to break it down into autonomous digital objects. Yet another relevant features are temporality and editability.

5. Shift from time invariant sources to frequently upgraded sources When book is published there is no way to upgrade it in another way than through new edition. Digital information resources, on the contrary, can be upgraded even on a daily basis. Again, from the point of view of law, each upgrade can be taken for a new "work".

\footnotetext{
* Martin Konvit

Faculty of Humanities, University of Zilina, Slovakia, E-mail: martin.konvit@fpv.uniza.sk

1) DOBRE, I.: Aspects related to Learning Content Management Systems. 2010.

2) AGNEV, G.: Digital rights management: a librarian's guide to technology and practice. 2008.

3) TEICH, A.H.: Technology and the Future Wadsworth Publishing. 2008.

4) Law No. 613/2003 Coll. on Copyright and Rights related to Copyright (Copyright Law). 2003.
} 


\section{Slovak Act on copyright}

Slovak Act on copyright and rights related to copyright (the Copyright Act - CA) is the principal source of copyright and neighboring rights. The philosophy of the CA comes out from Berne convention ${ }^{5}$. It does not require any formality to be fulfilled for obtaining a copyright protection of a work and no sign or notice need to be placed on a work in order to be copyright protected. Copyright subsists upon a work immediately when it is in a form perceivable by human senses. The CA is built around three key terms: the author, the work, the rights. No explicit definition of "the author" can be found in the CA. However, it is stated that the author shall be physical person who creates particular work with given attributes (e.g. creative processing of idea). A work is described as unique product of an author's own creative intellectual labor in a form perceivable by human senses. Moreover, by its nature, it has to be literary, scientific or artistic work. As for rights, they are of two kinds - moral and economic ones. There are two types of moral rights: the right of authorship (the right to sign a work with author's name, to use pseudonym or not to use any name) and the right of integrity of a work. Economic rights give the author an exclusive right to authorize any type of use of his/her work. "Any type" means literally all activities that can be performed upon a work - to copy it, to transmit/broadcast/display/ make available to public, to translate, to adapt, etc. While protection of the moral rights is not limited in time economic rights are granted to the author during his/her life plus seventy years after his/her death.

So called "library licence" ${ }^{\text {) }}$ allows libraries to lend traditional books and make copies under strictly defined conditions. Lending of books in a digital form is even more regulated - restrictions are placed especially on copying and online access. Restrictions on online access in fact do not allow libraries to offer their digitised information contents outside their premises.

Most of information resources used in educational process at universities (e.g. monographs, articles, etc.) have character of author work in a sense of the CA. Any type of use of these resources (including their digitization) can be done only on a basis of author's permission.

\section{Model of solution access to university information resources}

Design of model of access to university information resources is complex problem. It has its technological, managerial and legal aspects. The sequence of tasks to be solved is depicted in Fig. 1.

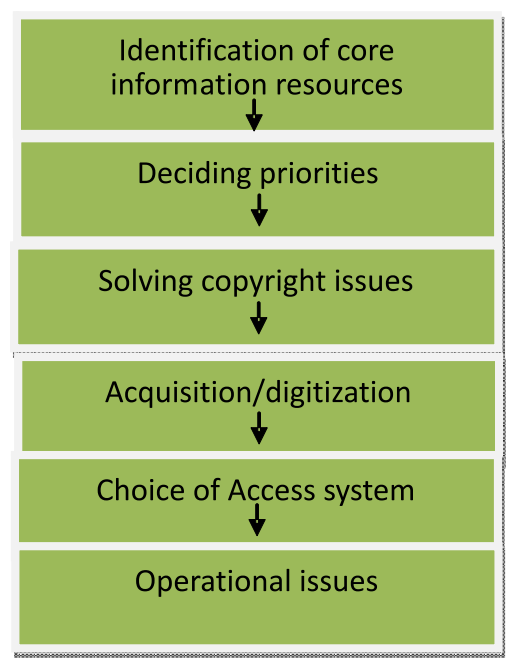

Fig. 1 Workflow of process of design of system of access to university information resources

From among all these activities we will focus our attention only on steps three "Solving copyright issues" and five "Choice of Access system"

\subsection{Solving copyright issues}

As we have already mentioned, most of information resources that should be included into system of university information resources are copyright protected. At the same time, however, authors of most of works come from members of university staff. This fact offers opportunity to solve copyright issues by one model agreement or only a few types of agreement. Right to make digital copies, right to migrate work on new physical carrier and right to make work online accessible have to be subject of agreement.

\subsection{Access model}

Two completely different models come into consideration free access or controlled (and eventually paid) access. It would be naïve to expect the authors would agree to provide works protected by the CA under free access model. This is why we will elaborate only on controlled access model in details.

Principles of controlled (paid) access to information resources have been articulated almost simultaneously with an emergence of digital information content. These principles are materialized in so called Digital Rights Management systems (DRM) $)^{7}$. DRM is

\footnotetext{
5) Berne Convention for the Protection of Literary and Artistic Works.1886.

6) SVIDRON, J. Basics of intellectual property law. 2000.

* Controlled acces is recommended in this case.

7) ROSENBLATT, W., TRIPPE, W., MOONEY, S.: Digital Rights Management. 2001.
} 
usually perceived as a complex system of protection of copyright related to digital information contents. However, DRM is by no means only another passive system of data protection. It provides also for digital management of rights through trading rights to particular digital content, license monitoring, rights owner monitoring, etc. Thus, DRM acts upon the triangle depicted in Fig. 2

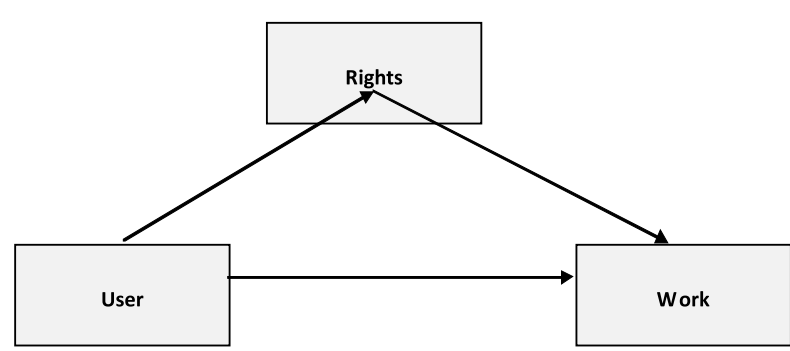

Fig. 2 Key entities in DRM

Though there is a strong opposition against implementation of DRM, the idea itself is backed by international organizations, e.g. WIPO ${ }^{8)}$, governments and European Union ${ }^{9}$. We recommend to apply principles of DRM in a system of university information resources. Such approach would allow for effective management of digital contents, rights related to these contents, monitor an access to them and their use. There are three fundamental types of rights that have to be managed in a system of $\mathrm{DRM}^{10)}$ :

1. Render rights (to print, to view, to execute - e.g. to play,
2. Transport rights (to copy, to loan, to move),

3. Derivative work rights (to edit, to extract, to embed).

Each user is given specific set of rights in a form of digital license. A license is extremely efficient tool for enforcing copyright. If particular right is not explicitly listed in a license then the system does not allow user to exploit it. Another advantage of licensing is possibility to grant rights on a basis of time (e.g. right of view for a month) or number of uses (e.g. five accesses to particular content).

\section{Conclusions}

Design of system of access to university information resources covers three at least equally important tasks: to find technological solution, to design managerial and operational structures and to solve copyright issues. While there are many both proprietary and open source technological solutions, design of managerial and operational structures has always to be adapted to given conditions and requirements and should take into account already existing environment. Solution of legal aspects is of different nature. Here is just a little room for "local solutions". Two documents have to be prepared - agreement and license. The license should be articulated in such a way that allows its subsequent transcription into algorithm implementable in DRM system.

Only key principles of system of access to university information resources were outlined in this article. Detailed design of system requires coordinated effort of the university top management, university library, faculties and departments.

\section{References}

[1] DOBRE, I.: Aspects Related to Learning Content Management Systems. In: Proc. of the $5^{\text {th }}$ Intern. Conference on Virtual learning (ICVL 2010), pp. 479-485, 2010.

[2] AGNEV, G.: Digital Rights Management: a Librarian's Guide to Technology and Practice. Oxford : Chandos Publishing, 2008. 437 p. ISBN: 978-1-84334-125-3, 2008.

[3] TEICH, A. H.: Technology and the Future. Boston : Wadsworth Publishing, 2008. 360 p. ISBN: 978-0534602772.

[4] Law Act No. 613/2003 Coll. on Copyright and the Related Rights (Copyright Law) [online]. 2003 [cit. 2011-05-15]. Available online: 〈http://www.culture.gov.sk/media-audiovizia/autorske-pravo-a-prava-suvisiace-s-autorskym-pravom/pravny-ramec〉.

[5] Berne Convention for the Protection of Literary and Artistic Works from 1886 [online]. [cit. 2011-05-15]. Available online: <http://www.wipo.int/treaties/en/ip/berne/trtdocs_wo001.html>.

[6] SVIDRON, J.: Basics of Intellectual Property Law. Bratislava : Juga, 2000. 252 p. ISBN 80-85506-93-9.

[7] ROSENBLATT, W., TRIPPE, W., MOONEY, S.: Digital Rights Management. New York: Wiley, 2001. 312 p. ISBN: 0-7645-4889-1.

[8] WIPO Copyright Treaty [online]. 1996 [cit. 2011-05-15]. Available online: 〈http://www.wipo.int/treaties/en/ip/wct/trtdocs_wo033.html>.

[9] Directive 2001/29/EC of the European Parliament and of the Council of 22 May 2001 [online]. 2001 [cit. 2011-05-15]. Available online: 〈http://eur-lex.europa.eu/LexUriServ/LexUriServ.do?uri=CELEX:32001L0029:EN:HTML>.

[10] STEFIK, M.: Internet Dreams - Archetypes, Myths, and Metaphors. Cambridge : MIT Press, 1996. 412 p. ISBN: 9780262193733.

\footnotetext{
8) WIPO Copyright Treaty. 1996.

9) Directive 2001/29/EC of the European Parliament and of the Council of 22 May 2001. 2001.

${ }^{10)}$ STEFIK, M.: Internet Dreams - Archetypes, Myths, and Metaphors.1996.
} 